\title{
O Deus de Jesus de Nazaré anunciado ao sujeito pós-moderno: Uma leitura a partir das cristologias de Edward Schillebeeckx e Jürgen Moltmann
}

\author{
Orientadora: Maria Clara Lucchetti Bingemer \\ Doutorando: Jayro Alves Soares \\ Área de Concentração: Teologia Sistemático-Pastoral \\ Linha de Pesquisa: Religião e Modernidade
}

Projeto de Pesquisa: A experiência do divino nas religiões do Livro

Esta pesquisa centra-se no estudo do tema O Deus de Jesus de Nazaré anunciado ao ser humano pós-moderno. Busca-se desenvolver o tema a partir das cristologias dos teólogos Edward Schillebeeckx e Jürgen Moltmann. A referida pesquisa visa à interação entre as imagens existenciais de Deus apresentadas pelos teólogos Schillebeeckx e Moltmann na práxis de Jesus de Nazaré, a fim de emoldurar bases para um resgate da genuína imagem humanizada e relacional de Deus para a vida do ser humano hodierno. O trabalho se desenvolve em quatro capítulos, que buscam estruturar esta tese: no primeiro descreve-se uma panorâmica construção da imagem existencial do ser humano, desde o paradigma racionalista moderno ao universo pós-moderno; no segundo propõe-se vislumbrar a face do Deus Abba de Edward Schillebeeckx em Jesus de Nazaré; no terceiro objetiva-se refletir sobre a face do Deus sofredor de Jürgen Moltmann em Jesus de Nazaré e no quarto, retomam-se os principais pontos das reflexões dos capítulos anteriores e pretende-se, a partir das leituras cristológicas de Schillebeeckx e Moltmann, propor, pelo enriquecimento peculiar de seus postulados, um resgate da imagem existencial do Deus anunciado por Jesus de Nazaré como modelo para uma reprodução ética fecunda à nossa época atual. As leituras cristológicas dos referidos teólogos propõem a imagem de um Deus sensibilizado, ávido por relacionar-se graciosamente com as pessoas e o mundo a sua volta. Uma sadia imagem a ser reproduzida pelo ser humano pós-moderno.

Palavras-chave: Pós-modernidade. Anúncio. Ser humano. 